\title{
Determining the spring biomass peak of the smallest plankters in selected vendace lakes in Western Pomerania
}

\author{
Józef Domagała, Łukasz Sługocki, Robert Czerniawski, Małgorzata Pilecka-Rapacz
}

Received - 10 February 2014/Accepted - 15 September 2014. Published online: 31 December 2014; $\odot$ Inland Fisheries Institute in Olsztyn, Poland Citation: Domagała J., Sługocki Ł., Czerniawski R., Pilecka-Rapacz M. 2014 - Determining the spring biomass peak of the smallest plankters in selected vendace lakes in Western Pomerania - Arch. Pol. Fish. 22: 289-297.

\begin{abstract}
The aim of this study was to determine the prevalence peak of the smallest plankters that are an adequate food resource for vendace (Coregonus albula L.) larvae. This goal was accomplished by determining weekly changes in zooplankton biomass, especially rotifers and nauplii, against changes in basic physicochemical parameters of lake waters. As the results of this paper show, the highest abundance of the smallest plankters, rotifers and nauplii, occurs at a particular temperature for a period of two weeks. The most important variable that determined the peak of small plankter biomass is temperature. Thus, the period of stocking lakes with vendace larvae should be synchronized with this temperature and the coinciding biomass peak of rotifers and nauplii, which are the basic food of vendace larvae.
\end{abstract}

Keywords: vendace larvae, inland fisheries, nauplii, rotifers

\section{Introduction}

Vendace, Coregonus albula L., is currently one of the most important species of the national Polish fish fauna from an economic point of view (Fiszer et al. 2012, Mickiewicz 2012). The main reasons for this

\footnotetext{
J. Domagała [ $\Xi^{\circ}$ ], Ł. Sługocki, R. Czerniawski, M. Pilecka-Rapacz Department of General Zoology

Faculty of Biology

University of Szczecin, Poland

ul. Felczaka 3c, 71-412 Szczecin

e-mail: Jozef.Domagala@univ.szczecin.pl
}

interest are its biological and consumer characteristics, i.e., shoal lifestyle and rapid growth, resulting in it achieving commercial volumes within two to three years, and, consequently, returning fry stocking costs in a relatively short time (Czerniejewski et al. 2003, Trella et al. 2012). According to these authors, these advantages and the relatively high price obtained for the excellent meat of these fish are the reasons why many fish farms have turned to the vendace management model, as it has a favorable impact on their economic outcomes (Czerniejewski et al. 2004).

Most of the lakes in western Poland do not offer mature vendace appropriate conditions for natural spawning. This is because of the accelerated eutrophication of lakes and the consequent silting of sandy bottom areas, loss of underwater meadows of stoneworts and mosses, and, in many cases, insufficient concentrations of dissolved oxygen or its lack in potential spawning grounds (Bernatowicz 1963, Żuromska 1982, Leopold and Wołos 1998). One of the treatments which facilitates maintaining vendace populations at a relatively high level is stocking, which is performed in lakes mainly with larvae or, less often, juvenile fish. However, this often does not produce the desired results, which can be ascribed to the lack of knowledge on the density of the first food of vendace, i.e. the smallest plankters, namely rotifers and nauplii, which later translates into lower fishing yields. However, it is quite difficult to 
determine the right time to stock larval material to ensure it has appropriate nutritional conditions. Therefore, in order to make the decision of when the right time is to release larvae into lakes, research on the dynamics of zooplankton biomass growth (especially its smallest elements) during the spring season should be conducted. In relation to changing environmental conditions, one should look for a parameter that indicates when there is abundant biomass growth of rotifers and nauplii. The aim of this study was to determine the prevalence peak of the smallest plankters that are an adequate food resource for vendace larvae. This goal was accomplished by determining weekly changes in zooplankton biomass, especially rotifers and nauplii, with regard to changes of basic physicochemical parameters of lake waters.

\section{Material and methods}

The studies were conducted in eight selected vendace lakes in the Western Pomerania Lake District, which differ mainly in morphometric parameters, altitude, and drainage: Bytyń (877 ha, mean depth $10.4 \mathrm{~m}$ ); Miedwie (3759 ha, mean depth $19.3 \mathrm{~m}$ ); Drawsko (1871 ha, mean depth $17.7 \mathrm{~m}$ ); Lubie (1439 ha, mean depth $11.6 \mathrm{~m}$ ); Siecino (729 ha, mean depth $14.1 \mathrm{~m}$ ); Ostrowieckie (387 ha, mean depth $9.4 \mathrm{~m}$ ); Marta (66 ha, mean depth $7.7 \mathrm{~m}$ );
Płociowe (35 ha, mean depth $10.3 \mathrm{~m}$ ) (Filipiak and Raczyński 2000) (Fig. 1). Lakes Ostrowieckie, Marta, and Płociowe are located within the boundaries of Drawa National Park so they are legally excluded from fisheries exploitation; however, these lakes were selected for comparison since they have quite different environmental conditions.

The samples of zooplankton were collected for more than two months; once a week from April 5 to June 14, 2013. The samples were collected from 100 $\mathrm{dm}^{3}$ of surface water by filtering it through a $10 \mu \mathrm{m}$ mesh at three designated points in each lake. Plankton qualitative determinations were made using the identification keys by Harding and Smith (1974), Rybak (2000), and Radwan (2004). In each sample the body length of at least 30 individuals of each species was measured with the Pixelink computer program. If the number of individuals representing a given species was lower than 30 , the body lengths of all individuals were measured. Body length was converted to mass with the Radwan (2004) tables.

During zooplankton sampling, water temperature, dissolved oxygen concentration, $\mathrm{pH}$, and electrolytic conductivity were also measured at each point with a multi-functional Elmentron CX 200 measurement device.

The statistical significance of differences in zooplankton biomass among the investigated lakes was determined using the non-parametric Kruskall-

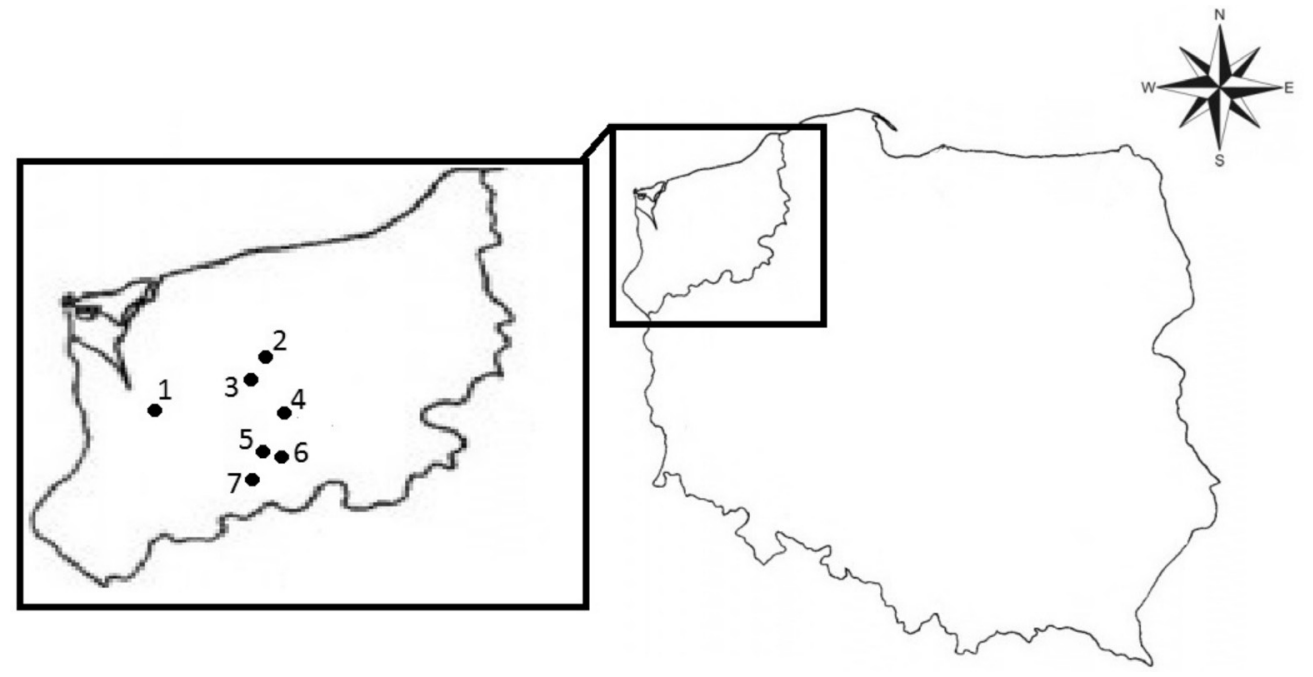

Figure 1. Study area, 1 Miedwie, 2 Siecino, 3 Lubie, 4 Bytyń, 5 Płociowe, 6 Marta, 7 Ostrowieckie. 
Wallis test $(\mathrm{P}<0.05)$. Statistical relationships between zooplankton biomass and values of physicochemical parameters were determined using linear correlation $(\mathrm{P}<0.05)$. In order to determine the correlation, the results obtained from the samples collected until May 31 were taken into account, because the biomass of rotifers and nauplii had remained relatively high until this time. In the following weeks, their biomass decreased dramatically, while the temperature of the lakes continued to rise. Thus, including the results of the subsequent two weeks would have disturbed the correlation result, and, consequently, determinations of the suitable moment to stock lakes with vendace larvae would not have been possible. In this case, the values of the physicochemical parameters are only an indicator of the onset of vendace larvae stocking in lakes. They do not determine the end period of this procedure, because later the biomass of the adequate food resource does not depend on physicochemical parameters but on biological indicators such as the density of predators or the amount of food. It should be emphasized that the authors did not address environmental changes of zooplankton biomass in time in this study, but rather focused on choosing the right moment to stock lakes with vendace larvae based on zooplankton biomass.

\section{Results and Discussion}

\section{Physicochemical conditions of the lakes}

Despite environmental differences, the investigated lakes were characterized by rather similar values of basic physicochemical parameters (Fig. 2). The lakes did not differ significantly in the values of these parameters, except for conductivity, the value of which was significantly higher in Miedwie than in the other lakes $(\mathrm{P}<0.001)$. This is because of the runoff of territorial pollutants into the lake waters by rivers and from the direct drainage basin that is not forested, and which, if it were, could have acted as a buffer zone (Smal et al. 2005). Conductivity values were similar in the other lakes. Despite the similarity of the other parameters, we observed small, but insignificant differences among the lakes. The lakes located in Drawa National Park had higher temperatures and lower concentrations of dissolved oxygen than did the remaining lakes at the same time. The lowest temperature was recorded in Drawsko, the reservoir with the largest area, the greatest depth, and the highest altitude. Such lakes are characterized by the lowest average annual temperature values and nutrient contents (Seip et al. 1991). The $\mathrm{pH}$ values in all of the lakes were similar.

\section{Relationships between zooplankton biomass and basic physicochemical parameters}

A strong positive correlation between water temperature and $\mathrm{pH}$ and the biomass of rotifers and nauplii was observed $(\mathrm{P}<0.01)$ (Table 1). Furthermore, the biomass of rotifers correlated significantly positively with dissolved oxygen concentration $(\mathrm{P}<0.05)$. As in the case of the smallest taxa, the biomass of crustaceans also correlated significantly positively with water temperature (Cladocera and Copepoda) and $\mathrm{pH}$ (Copepoda) $(\mathrm{P}<0.05)$. This correlation suggest that the parameters of temperature and $\mathrm{pH}$ are the most important, and that they could have a crucial impact on the biomass growth of rotifers and nauplii that are a potential food resource for vendace larvae, and thus on choosing the right moment to begin larvae stocking. Based on the results of the study of the physicochemical conditions of lake waters and the dynamics of biomass change of nauplii and rotifers, it was found that the increase in the biomass of the smallest plankters occurred in each lake at a water temperature above $15^{\circ} \mathrm{C}$ and a $\mathrm{pH}$ value very close to or greater than 9 (Fig. 2).

Temperature and $\mathrm{pH}$ are important physicochemical parameters that play an important role in the growth of zooplankton biomass, especially that of rotifers (Radwan 2004). Zooplankton biomass increases with increases of temperature and $\mathrm{pH}$, as confirmed by the results of this study. However, the 
increase of $\mathrm{pH}$ in lakes probably also depends on temperature and is proportional to sunlight. Together they affect the growth of primary production, which, in turn, has an impact on $\mathrm{pH}$ changes (Maberly 1996). Therefore, the best parameter that indicates the appropriate time for stocking lakes with vendace larvae is when temperature is higher than $15^{\circ} \mathrm{C}$. It is worth remembering that rises in water temperature caused increases in the biomass of small plankters only until a certain time. The sudden increase in the biomass of small plankters could have been reduced at a later time by the development of predatory fish larvae and juvenile fish, as has been observed in other lakes by Mehner and Thiel (1999), so the decline in their biomass might not have been caused by further temperature rise but by the presence of predatory fish. The development of small plankters occurs before Coregonidae and Cyprinidae fish larvae hatch. These larvae then have access to abundant food resources composed of rotifers and nauplii (Karjalajnen 1992, Hansson et al. 2007). After absorbing most of the yolk sac supply, the early life stages of these fish larvae feed on rotifers and nauplii. Then, when they grow to larger sizes and when the biomass of the small plankters decreases, they eat food of larger sizes such as copepodits of copepods and their mature stages as well as mature Cladocera (Mehner and Thiel 1999).

\section{Differences in zooplankton biomass between the lakes}

Considering the availability of food resources for vendace hatching, the most attention was focused on rotifers and nauplii, the smallest components of the investigated zooplankton. The largest biomass of these plankters was observed in Lubie (a total of 533 $\mu \mathrm{g} \mathrm{dm}^{-3}$ ). The average biomass of rotifers and nauplii in the other lakes (Bytyń and Ostrowieckie) was almost twice lower at $287 \mathrm{mg} \mathrm{dm}^{-3}$ and $282 \mathrm{mg} \mathrm{dm}^{-3}$, respectively. In Drawsko and Miedwie, the average biomass value of these two taxa was $156 \mu \mathrm{g} \mathrm{dm}^{-3}$ and $148 \mu \mathrm{g} \mathrm{dm}^{-3}$, respectively. On the other hand, their lowest average biomass was observed in Siecino (62 $\left.\mu \mathrm{g} \mathrm{dm}^{-3}\right)$, Marta $\left(41 \mu \mathrm{g} \mathrm{dm}^{-3}\right)$, and Płociowe $(6 \mu \mathrm{g}$ $\mathrm{dm}^{-3}$ ) (Table 2). The biomass of rotifers and nauplii in these three lakes was significantly lower than in the other lakes in almost every case $(\mathrm{P}<0.05)$ (Table 2). Relatively high biomass of the smallest plankters occurred in lakes surrounded by rural catchment

Table 1

Results of simple correlations between zooplankton biomass and values of basic physicochemical variables, ${ }^{*} \mathrm{P}<0.05$;

$* * \mathrm{P}<0.01$

\begin{tabular}{lllll}
\hline \hline Variable & Rotifera & Nauplii & Cladocera & Copepoda \\
\hline \hline Temperature & $0.444^{* *}$ & $0.403^{* *}$ & $0.277^{*}$ & $0.287^{*}$ \\
Dissolved oxygen & $0.275^{*}$ & -0.161 & -0.192 & -0.136 \\
pH & $0.444^{*}$ & $0.476^{* *}$ & 0.065 & $0.271^{*}$ \\
Conductivity & 0.182 & 0.144 & 0.144 & 0.130 \\
\hline \hline
\end{tabular}

Table 2

Mean \pm SD biomass $\left(\mu \mathrm{g} \mathrm{dm}^{-3}\right)$ of zooplankton in the lakes studied. Different letters in columns indicate significant differences among lakes $(\mathrm{P}<0.05)$. Lakes Marta, Ostrowieckie, and Płociowe were tested with other lakes from 05.16 to 06.12

\begin{tabular}{lllll}
\hline \hline Lake & Rotifera & Nauplii & Cladocera & Copepoda \\
\hline \hline Bytyń & $241^{\mathrm{a}} \pm 269$ & $46^{\mathrm{a}} \pm 73$ & $62^{\mathrm{a}} \pm 87$ & $60^{\mathrm{ae}} \pm 138$ \\
Drawsko & $94^{\mathrm{a}} \pm 117$ & $62^{\mathrm{a}} \pm 83$ & $4^{\mathrm{b}} \pm 8$ & $46^{\mathrm{ae}} \pm 53$ \\
Lubie & $489^{\mathrm{a}} \pm 639$ & $64^{\mathrm{a}} \pm 92$ & $170^{\mathrm{a}} \pm 288$ & $287^{\mathrm{ad}} \pm 425$ \\
Miedwie & $106^{\mathrm{a}} \pm 111$ & $32^{\mathrm{a}} \pm 69$ & $51^{\mathrm{a}} \pm 55$ & $44^{\mathrm{ae}} \pm 53$ \\
Siecino & $42^{\mathrm{bc}} \pm 56$ & $20^{\mathrm{ab}} \pm 32$ & $25^{\mathrm{ab}} \pm 45$ & $11^{\mathrm{bd}} \pm 13$ \\
Marta & $26^{\mathrm{bc}} \pm 14$ & $15^{\mathrm{b}} \pm 16$ & $98^{\mathrm{c}} \pm 65$ & $62^{\mathrm{de}} \pm 42$ \\
Ostrowieckie & $254^{\mathrm{ab}} \pm 185$ & $28^{\mathrm{a}} \pm 20$ & $667^{\mathrm{d}} \pm 670$ & $76^{\mathrm{e}} \pm 76$ \\
Płociowe & $8^{\mathrm{c}} \pm 3$ & $2^{\mathrm{c}} \pm 1$ & $22^{\mathrm{c}} \pm 21$ & $7^{\mathrm{ce}} \pm 6$ \\
\hline \hline
\end{tabular}



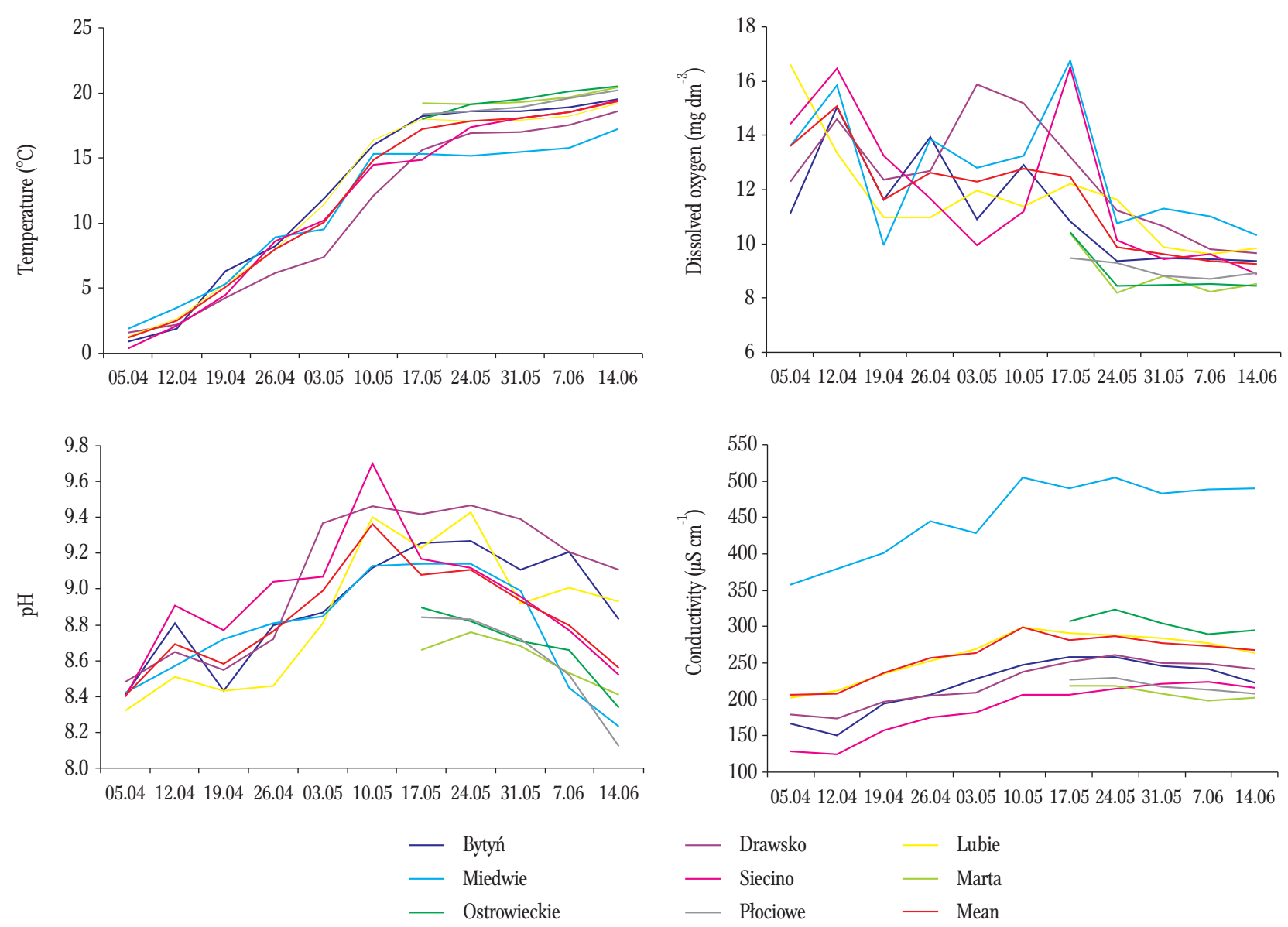

Figure 2. Weekly changes in basic physicochemical variables in the lakes studied.

areas, namely Lubie, Bytyń, Miedwie, and Drawsko. Human activity in the lake catchments has the greatest impact on increased trophic status (Smal et al. 2005). Consequently, the increase of the water trophy leads to the rapid increase of rotifer biomass (Radwan 2004).

The biomass of crustaceans (Cladocera and Copepoda) was the largest in Lake Ostrowieckie, followed by Lubie. The smallest average biomass value of crustaceans was observed in Płociowe and Siecino (Table 2). The reasons for the high crustaceans biomass in the lakes are similar to those for rotifers. The dominants in crustaceans biomass were species typical for waters with high trophic status.

\section{Percentage of rotifers and nauplii in total zooplankton biomass}

In most of the investigated lakes the structure of the average zooplankton biomass was shaped mainly by the smallest zooplankton components, i.e., rotifers and nauplii (Table 2). In Bytyń, Drawsko, Lubie, and Miedwie, rotifers and nauplii accounted for 70, 61, 54 , and $61 \%$ of the average zooplankton biomass, respectively. Furthermore, as mentioned above, the average biomass of these taxa was relatively high. The higher percentage of rotifers and nauplii than adult crustaceans in the biomass indicates the high trophic status of the lake (Radwan 2004). In Siecino, rotifers 

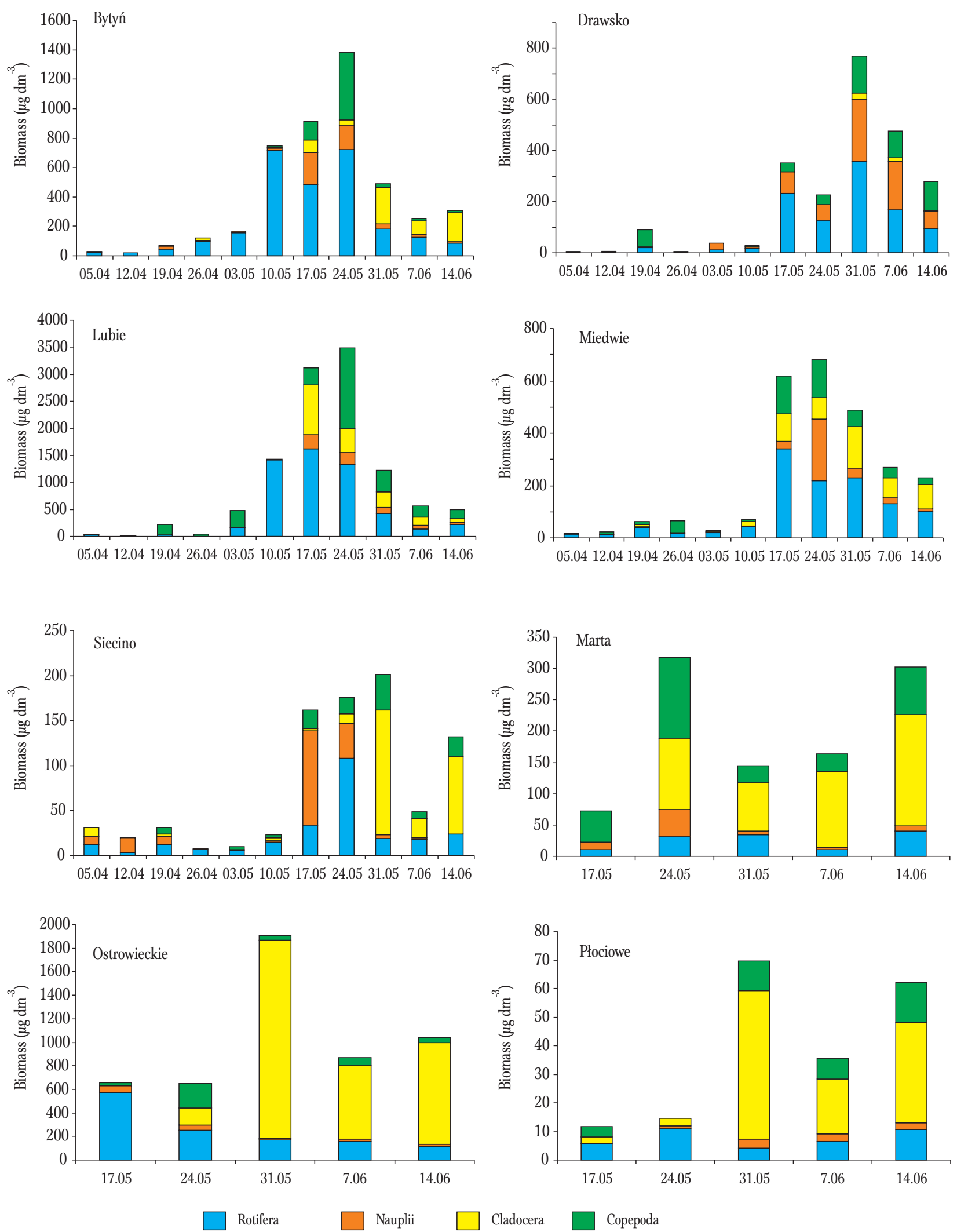

Figure 3. Weekly changes in zooplankton biomass in the lakes studied. 
and nauplii constituted a high percentage of the average biomass compared to the entire zooplankton biomass (63\%); nevertheless, the absolute biomass value of all zooplankton taxa in this lake was low. In contrast, there was a small percentage (only 27\%) of rotifers and nauplii in the average zooplankton biomass in Lake Ostrowieckie, but the average biomass of these two taxa was still relatively high. The smallest percentage of rotifers and nauplii in the average zooplankton biomass was recorded in Płociowe (17\%) and Marta (20\%). Moreover, as mentioned above, the average biomass of these two groups in these lakes was also low, and was probably caused by the low trophic status of these lakes and favorable conditions of their catchment areas, which are primarily forested.

\section{Weekly changes in biomass of zooplankton taxonomic groups}

In all the investigated lakes, except for Płociowe and Marta, the continuous dominance of rotifers and nauplii over crustaceans was observed until the biomass peak of rotifers and nauplii was reached (Fig. 3). From the moment the biomass of these taxa increased, a higher percentage of them in the zooplankton biomass was observed for at least two weeks. In subsequent weeks, the percentage of crustaceans in the zooplankton biomass increased. This is a typical phenomenon that occurs in lakes in spring. Until the end of April, the zooplankton biomass should be dominated by rotifers, while larger crustaceans start to dominate following the period of intense small fish predation (Xie et al. 1998, Mehner and Thiel 1999). The number of predatory fish larvae and fry in lakes has a crucial impact on zooplankton biomass (Gliwicz and Pijanowska 1989, Hansson et al. 2007). Another factor contributing to the decline of zooplankton biomass is the depletion of its food resources (Hansson et al. 2007). In the initial period, small plankters such as rotifers and nauplii become strongly reduced, and when fish have grown to a larger size, the same happens to copepodits of copepods and mature crustaceans (Cryer et al. 1986, 1986, Hrbacek et al. 1961, Helminen et al. 1990).

\section{Weekly changes in rotifer and nauplius biomass-available food resource for vendace larvae}

A sudden increase in the biomass of rotifers and nauplii in all the lakes was observed in May. The average biomass of all the lakes indicates that this was sustained for two weeks in May. However, despite this similarity, it did not proceed in all the lakes at the same time, which seems to be caused by various hydrological and geographic conditions in the investigated reservoirs (Fig. 4). In Lubie and Bytyń a sudden

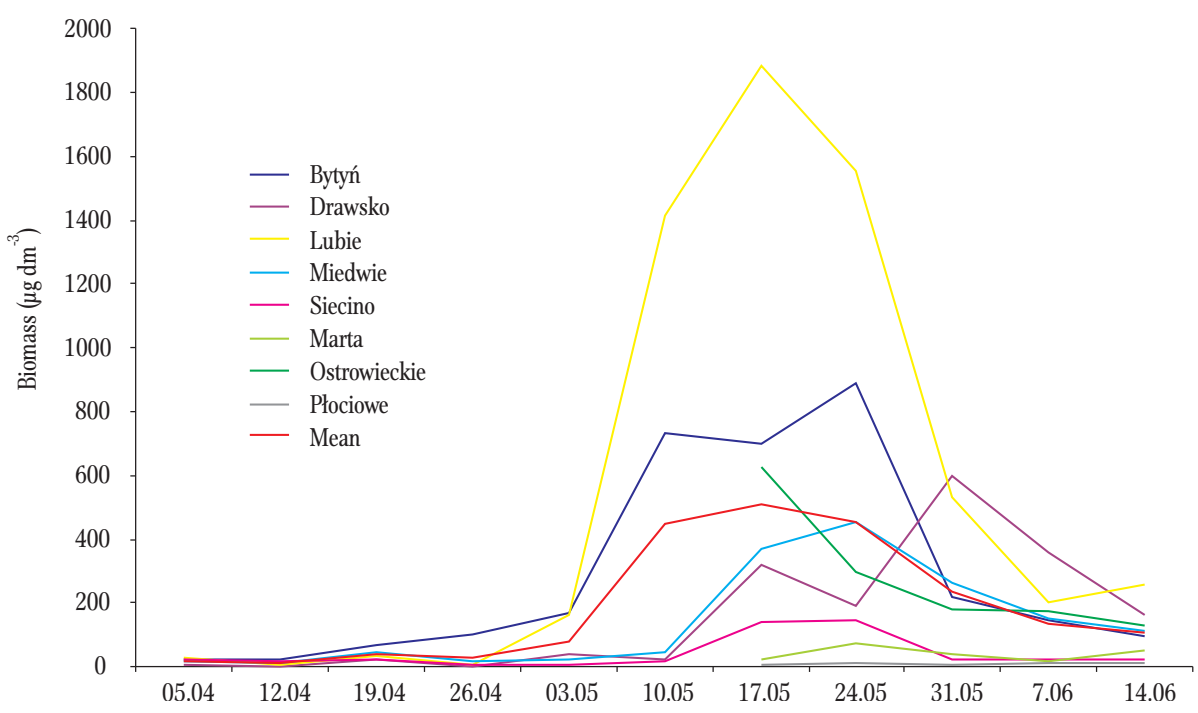

Figure 4. Weekly changes in food base biomass - nauplii and rotifers - that were available for vendace larvae in the lakes studied. 
increase was recorded on May 10, while in Miedwie, Drawsko, Siecino, and Ostrowieckie, the biomass increase was delayed by a week (May 17). In the last two small lakes (Płociowe and Marta) the increase in biomass of rotifers and nauplii was negligible. After about two to three weeks of a relatively high biomass level of these taxa, a significant decrease in rotifer and nauplius biomass was observed in all the lakes. This indicates that lakes should be stocked with vendace larvae during this period so they can survive and grow.

\section{Conclusion}

Taking into account the above results, it can be concluded that most of the lakes have favorable nutrient conditions for vendace larvae. The biomass peak of rotifers and nauplii lasted for two weeks. It should also be noted that 2013 was an unusual year because of the exceptionally long winter, and the peak of rotifer biomass occurred later than usual. Also, vendace larvae appeared in hatcheries in mid-April, two to three weeks later than usual. This indicates that the vendace hatching season is not synchronized with increased rotifer biomass and occurs too early in relation to the abundance of suitable food in lakes. Therefore, in order to succeed, lake stocking should be preceded by the extended incubation of spawn or growing larvae until it reaches the early juvenile fish stage. In any case, vendace larvae hatch in hatcheries long before adequate food resources are available in the lakes. Thus, the period of vendace larva lake stocking might not be synchronized with the biomass peak of the rotifers and nauplii that are the basic food for the larvae. As the results of this paper show, the abundance of the smallest plankters, rotifers and nauplii, occurs at a particular temperature for a period of two weeks. This relationship should be taken into account in rational vendace management.

Author contributions. J.D, Ł.S., R.C. and M.P.R. designed and performed the experiment, analyzed the data, and wrote the manuscript.

\section{References}

Bernatowicz S. 1963 - Observations of vendace spawning in the Lake Mamry complex - Rocz. Nauk Rol. 82: 339-352 (in Polish).

Cryer M., Peirson G., Townsend C. R. 1986 - Reciprocal interactions between roach, Rutilus rutilus, and zooplankton in a small lake: prey dynamics and fish growth and recruitment - Limnol. Oceanogr. 31: 1022-1038.

Czerniejewski P., Filipiak J., Czerniawski R. 2003 - Absolute and relative fecundity in vendace (Coregonus albula $\mathrm{L}$.) from Western Pomeranian lakes - Komun. Ryb. 4: 15-18 (in Polish).

Czerniejewski P., Lewita O., Świątek H., Cieszkowski K., Czerniawski R. 2004 -Applying agglomeration analysis in evaluations of morphometric differentiation among vendace from chosen lakes in Western Pomerania Komun. Ryb. 4: 28-31 (in Polish).

Filipiak J., Raczyński M. 2000 - Western Pomeranian Lakes (a factual outline) - Wyd. AR, Szczecin (in Polish).

Fiszer M., Przybył A., Andrzejewski W., Mazurkiewicz J., Golski J., Przybylska K., Runowski S. 2012 - Effects of eutrophication on vendace, Coregonus albula (L.). II. Biological characteristics of vendace from selected lakes in Wielkopolska - Arch. Pol. Fish. 20: 97-108.

Gliwicz Z.M., Pijanowska J. 1989 - The role of predation in zooplankton succession - In: Plankton Ecology. Succesion in Plankton Communities (Ed.) U. Sommer, Springer-Verlag, Berlin, Heidelberg, New York, London, Paris, Tokyo: 253-296.

Hansson L.A., Nicolle A., Brodersen J., Romare P., Nilsson P. A., Brönmark C., Skov C. 2007 - Consequences of fish predation, migration, and juvenile ontogeny on zooplankton spring dynamics - Limnol. Oceanogr. 52: 696-706.

Harding J.P., Smith W.A. 1974 - A key to the British freshwater cyclopid and calanoid copepods - FBA Special Publication, 18, Far Sawrey, Cumbria: Freshwater Biological Association.

Helminen H., Sarvala J., Hirvonen A. 1990 - Growth and food consumption of vendace (Coregonus albula (L.)) in Lake Pyhäjärvi, SW Finland: a bioenergetics modeling analysis - In: Biomanipulation tool for water management (Eds) R.D. Gulati, E.H.R.R. Lammens, M-L., Meijer, E. van Donk, Amsterdam 8-11.08.1989, Repr. from Hydrobiologia: 200/201: 511-522.

Hrbácek J., Dvorakova M., Korinek V., Procházkóva L. 1961 Demonstration of the effect of the fish stock on the species composition of zooplankton and the intensity of metabolism of the whole plankton association - Verh. Int. Ver. Theor. Angew. Limnol. 14: 192-195.

Karjalajnen J. 1992 - Food ingestion, density-dependent feeding and growth of vendace (Coregonus albula (L.)) larvae - Ann. Zool. Fenn. 29: 93-103. 
Leopold M., Wołos A. 1998 - Effectiveness of vendace stocking as affected by stocking frequencies - Pol. Arch. Fish. 6: 289-293.

Maberly S.C. 1996 - Diel, episodic and seasonal changes in $\mathrm{pH}$ and concentrations of inorganic carbon in a productive lake - Freshwat. Biol. 35: 579-598.

Mehner T., Thiel R. 1999 - A Review of Predation Impact by $0+$ Fish on Zooplankton in Fresh and Brackish Waters of the Temperate Northern Hemisphere - Environ. Biol. Fish. 56: 169-181.

Mickiewicz M. 2012 - Comparison of mean prices of commercial fish and stocking material used by fishing enterprises in fisheries districts in 2009 and 2010 - Komun. Ryb. 1: 2-6 (in Polish).

Radwan S., Bielańska-Grajner I., Ejsmont-Karabin J., 2004 General part, Monogononta - systematic part, 32.A. - In: Rotifers (Rotifera) Polish Freshwater Fauna (Ed.) S. Radwan, Polskie Towarzystwo Hydrobiologiczne, Uniwersytet Łódzki, Oficyna Wydawnicza Tercja, Łódź, 146 p. (in Polish).
Rybak J.I. 2000 - Freshwater Invertebrates - PWN, Warszawa (in Polish).

Seip K.L., Sas H., Vermij S. 1992 - Changes in secchi disk depth with eutrophication - Arch. Hydrobiol. 124: 149-165.

Smal H., Kornijów R, Ligęza S., 2005 - The effect of catchment on water quality and eutrophication risk of five shallow lakes (Polesie Region, eastern Poland) - Pol. J. Ecol. 53: 313-327.

Trella M., Fopp-Bayat D., Szczepkowski M., Polak A. 2012 Genetic characterization of vendace, (Coregonus lavaretus, L. 1758) from Lake Wisztynieckie using microsatellite DNA markers - Komun. Ryb. 4: 11-16 (in Polish).

Xie P., Iwakuma T., Furii K. 1998 - Changes In the structure of zooplankton community during a Ceratium (dinoflagellate) bloom in a eutrophic fishless pond - J. Plankton Res. 20: 1663-1678.

Żuromska H. 1982 - Conditions of natural reproduction of Coregonus albula (L.) and Coregonus lavaretus (L.) - Pol. Arch. Fish. 29: 1-28. 